\title{
Analisis Kepuasan Pasien Bpjs Rawat Jalan Dengan Metode Servqual, CSI dan IPA di Klinik Dr. M. Suherman
}

\author{
Atma Deharja ${ }^{1 *}$, Fitriana Putri ${ }^{2}$, Ludvi Oktaviotika Nasikhatul Ikawangi ${ }^{1}$ \\ ${ }^{1}$ Jurusan Kesehatan, Politeknik Negeri Jember \\ ${ }^{2}$ Prodi S1 Keperawatan, Universitas Muhammadiyah Jember \\ atma.deharja@gmail.com*
}

\begin{abstract}
Problems that related to patient satisfaction still happening in health care. One of the institutions that administer health care is clinic. Clinic dr. M. Suherman is first level clinics that cooperate with BPJS in provided services to patients. Monthly report data of the number of BPJS patient visits that receive outpatient services at the Clinic dr. M. Suherman in 2015 outline increased from $40.73 \%$ in January to $62.52 \%$ in December. However, increasing of the number of patient visits are not always accompanied by an increase of patient satisfaction. The first observations of 14 BPJS patients who received outpatient care showed that 9 of them stated that the service less than satisfactory. The purpose of this research is identify the perceptions and expectations based on five dimensions of quality, measuring the level of BPJS patient satisfaction to outpatient services, and analyze the level of patient satisfaction based mapping. Methods of processing the data in this study using SERVQUAL and Customer Satisfaction Index (CSI) method to measure the level of patient satisfaction. Importance Peformance Analysis (IPA) method is used to analyze the priority problem for the improvement of service quality. The results with SERVQUAL method showed that the highest gap is the dimension of responsiveness. Customer Satisfaction Index (CSI) method stated that the percentage of patient satisfaction is 79.958\%. The results of the analysis by Importance Peformance Analysis (IPA) method stated that there are 5 attributes in the top priority.
\end{abstract}

Keywords: BPJS Patient Satisfaction, CSI, IPA, Servqual

\section{Pendahuluan}

Menurut Pohan (2007) menciptakan layanan kesehatan yang semakin responsif dan fokus terhadap kebutuhan masyarakat merupakan suatu tujuan utama. Menurut Gupta dalam Puspitasari (2013) menyatakan bahwa kinerja suatu layanan kesehatan dalam memberikan kualitas pelayanan yang memuaskan pasien menjadi sangat penting bagi masyarakat. Disisi lain Pohan (2007) menyatakan bahwa pandangan pasien terhadap kepuasan pelayanan sangat penting karena pasien akan mematuhi pengobatan serta mau datang berobat kembali. Maka penting bagi penyelenggara layanan kesehatan untuk memberikan pelayanan yang memuaskan bagi pasien.

Salah satu institusi yang menyelenggarakan pelayanan kesehatan adalah Klinik. Klinik dr. M Suherman merupakan klinik pratama yang berlokasi di Jalan Karimata No.49 Kabupaten Jember yang disediakan oleh perguruan tinggi Universitas Muhammadiyah Jember serta telah bekerja sama dengan BPJS Kesehatan dalam memberikaan pelayanan kepada pasien.

Berdasarkan hasil observasi awal pada tanggal 18 Mei 2016 tentang kepuasan pasien BPJS di Klinik dr. M. Suherman yang mendapatkan pelayanan rawat inap dan rawat jalan, diperoleh hasil bahwa pasien yang mendapatkan pelayanan rawat jalan lebih banyak memberikan keluhan dibandingkan dengan pasien yang mendapatkan pelayanan rawat inap di Klinik dr. M. Suherman. Dibuktikan pada hasil observasi awal tersebut bahwa dari 14 pasien BPJS di Klinik dr. M. Suherman yang mendapatkan pelayanan rawat jalan, terdapat 5 pasien menyatakan pelayanan memuaskan dan 9 pasien menyatakan bahwa pelayanan kurang memuaskan atau kurang sesuai harapan.

Menurut Puspitasari (2013) konsumen pelayanan kesehatan akan membandingkan 
pelayanan kesehatan yang diterima dengan harapan terhadap pelayanan yang diberikan sehingga membentuk tingkat kepuasan. Tingkat kepuasan pasien menunjukkan tingkat keberhasilan suatu layanan kesehatan dalam meningkatkan mutu pelayanannya. Pengukuran tingkat kepuasan pasien dapat dilakukan dengan menggunakan berbagai metode pengukuran. Dari beberapa metode yang ada, berbagai riset menunjukkan bahwa instrumen Service Quality (Servqual) valid untuk berbagai konteks layanan (Mustaniroh, dkk.,2010). Metode Servqual mempunyai kelebihan yaitu dapat mengetahui tingkat kepuasan pelanggan pada setiap atribut pelayanan, namun metode ini memiliki kekurangan yaitu penilaiannya secara subyektif dan perbaikan kualitas layanan hanya berdasarkan pada gap yang memiliki nilai tertinggi saja. Sehingga untuk menutupi kekurangan pada metode ini perlu adanya integrasi dengan metode lain, yaitu metode Customer Satisfaction Index (CSI) dan Importance Performed Analysis (IPA).

Metode Customer Satisfaction Index (CSI) memiliki keunggulan mudah digunakan dan sederhana serta menggunakan indeks kepuasan dengan skala yang memiliki sensitivitas dan reliabilitas cukup tinggi. Menurut Wahono dalam Rahayu (2016) metode Importance Performance Analysis (IPA) mampu memetakan persepsi pelanggan terhadap tingkat kepentingan (importance) aspek pelayanan dengan persepsi pelanggan terhadap kinerja (performance) dari aspek pelayanan untuk mengidentifikasi layanan yang perlu ditingkatkan untuk menjaga kepuasan pelanggan, hasilnya relatif mudah diinterpretasikan, skalanya relatif mudah dimengerti dan membutuhkan biaya yang rendah. Perpaduan tiga metode ini sesuai dengan tujuan pada penelitian ini yaitu mengukur tingkat kepuasan pasien serta dapat mengetahui perbaikan yang harus dilakukan oleh klinik dalam upaya peningkatan mutu pelayanan kesehatan.

\section{Metodologi penelitian}

Penelitian ini menggunakan metode deskriptif dengan teknik analisis kuantitatif. Penelitian dilakukan pada bulan AgustusOktober 2016 di Klinik dr. M. Suherman Jalan Karimata No. 49, Kecamatan
Sumbersari, Kabupaten Jember yang merupakan salah satu klinik pratama yang berkerjasama dengan Badan Penyelenggara Jaminan Kesehatan.

Populasi penelitian adalah total pasien BPJS yang mendapatkan pelayanan rawat jalan di Klinik dr. M. Suherman tahun 2015 terhitung pada bulan Agustus-Oktober sebanyak 6182 dengan sampel yang diperoleh adalah 99 pasien. Dalam penelitian ini pengumpulan data dilakukan dengan cara memberikan kuisioner kepada responden yaitu pasien BPJS yang mendapatkan pelayanan rawat jalan di Klinik dr. M. Suherman. Kuesioner yang diajukan berisi pernyataan tentang persepsi atau kinerja dan harapan pasien. Pernyataan persepsi untuk menilai tentang bagaimana pelayanan yang didapat di Klinik dr. M. Suherman, sedangkan pernyataan harapan yaitu pernyataan yang dibuat untuk mengetahui harapan pasien terhadap pelayanan yang diberikan sebagai suatu masukan bagi klinik atau pihak pemberi layanan. Pernyataan yang ada dalam kuesioner ini merupakan atribut-atribut dari 5 dimensi mutu layanan kesehatan yaitu :

1. Bukti Langsung (Tangible)

A1 Klinik memiliki lokasi yang strategis, mudah dijangkau oleh kendaraan umum

A2 Ruang tunggu luas, dimana terdapat cukup tempat untuk menunggu tanpa berdesakan dengan orang lain

A3 Tempat parkir luas ditandai dengan terdapat cukup tempat untuk menampung kendaraan serta terdapat jalan untuk keluar masuk kendaraan yang diparkir

A4 Ruang pemeriksaan terasa nyaman dengan adanya pendingin udara yang berfungsi dengan baik

A5 Ruang pemeriksaan dalam kondisi bersih, tidak terdapat sampah berceceran sampah bekas alat suntik

A6 Ruang tunggu nyaman dimana terdapat media hiburan dan pendingin udara yang benar-benar berfungsi dengan baik

A7 Ruang tunggu bersih, bebas dari segala sampah dan kotoran

A8 Baju dokter bersih, terbebas dari segala kotoran termasuk noda darah 
A9 Baju perawat bersih, terbebas dari segala kotoran termasuk noda darah

A10 Penampilan dokter selalu rapi, baju bersifat sopan dan tidak kusut

A11 Penampilan perawat selalu rapi, baju bersifat sopan dan tidak kusut

A12 Kamar mandi dalam kondisi bersih, tidak terdapat kotoran dalam bak air maupun kotoran yang menyumbat saluran air

A13 Terdapat mushola dalam kondisi bersih, tidak terdapat sampah atau kotoran yang menyebabkan najis

A14 Terdapat kotak saran serta alat tulisnya untuk menampung saran dari pasien maupun keluarga

A15 Terdapat Pusat pengaduan atau customer service yang dapat dihubungi langsung dibagian pengaduan atau via telepon

A16 Terdapat Kamera CCTV untuk memantau segala kegiatan di Klinik

2. Kehandalan (Reliability)

B17 Dokter melayani pasien dengan tepat, yaitu melakukan pemeriksaan yang diperlukan sesuai dengan keluhan pasien. Contoh : pasien mengeluh demam, dilakukan pemeriksaan suhu tubuh

B18 Perawat melayani pasien dengan segera setelah pasien datang dan tepat sesuai dengan instruksi / perintah dokter

B19Dokter telah hadir diruang pemeriksaan dan siap melayani pasien ketika jam buka rawat jalan dimulai (pagi : 08.00-13.00, sore 16.00-21.00)

B20 Dokter mampu memberikan informasi hasil pemeriksaan yang telah dilakukan dengan jelas dan mudah dimengerti oleh pasien

B21 Penjelasan perawat mudah dimengerti oleh pasien

3. Daya Tanggap (Responsiveness)

C22 Dokter cepat tanggap, segera mengetahui gejala sakit yang ada serta segera memberikan penanganan terhadap keluhan pasien

C23 Perawat cepat tanggap, segera memberikan penanganan sesuai instruksi dokter terhadap keluhan pasien

C24 Waktu tunggu pasien untuk mendapatkan pelayanan rawat jalan kurang dari 60 menit

C25 Waktu tunggu pasien untuk mendapatkan obat dari apotek kurang dari 30 menit

C26 Petugas kebersihan selalu tanggap melaksanakan tugasnya apabila ruangan terlihat kotor

4. Jaminan (Assurance)

D27 Klinik menjaga sterilisasi fasilitas pelayanan kesehatan

D28 Dokter menjaga kebersihan dengan menggunakan sarung tangan atau selalu mencuci tangan sebelum memberikan pelayanan kepada pasien

D29 Dokter mempunyai pengetahuan dalam memberikan terapi ditandai dengan mampu dan cekatan melakukan pemeriksaan, menetapkan diagnosis berdasarkan keluhan yang disampaikan pasien dan pemeriksaan yang dilakukan

D30 Perawat mempunyai pengetahuan dalam memberikan perawatan ditandai dengan mampu dan cekatan dalam melaksanakan tugas yang diinstruksikan oleh dokter

D31 Petugas pendaftaran melayani dengan senyum, sapa dan salam

D32 Petugas apotek melayani dengan senyum, ramah dan sopan

D33 Jaminan bahwa kerahasiaan informasi pasien (identitas sosial maupun kondisi sakit pasien) dapat terjaga dengan baik

D34 Petugas parkir memiliki tanggung jawab terhadap kendaraan yang dijaga dengan tidak meninggalkan area parkir serta memperhatikan area parkir

5. Empati (Emphaty)

E35 Dokter memberikan pelayanan tanpa memandang status sosial pasien, baik pasien kaya, kurang mampu, pasien dengan BPJS kelas 3, 2 maupun 1 
E36 Perawat memberikan pelayanan tanpa memandang status sosial pasien, baik pasien kaya, kurang mampu, pasien dengan BPJS kelas 3, 2 maupun 1

E37 Dokter memberikan perhatian kepada pasien dibuktikan dengan dokter mendengarkan keluhan dan ungkapan perasaan pasien tanpa memotong pembicaraan, serta memberikan kata dukungan atau penyemangat (Semoga lekas sembuh)

E38 Perawat memberikan perhatian terhadap pasien dengan mendengarkan keluhan dan ungkapan perasaan pasien tanpa memotong pembicaraan, serta memberikan kata dukungan atau penyemangat (Semoga lekas sembuh)

E39 Dokter selalu menghormati hak pasien dengan meminta izin (secara lisan) sebelum melakukan pemeriksaan

E40 Perawat selalu menghormati hak pasien dengan meminta izin (secara lisan) sebelum melakukan pemeriksaan

E41 Ketika terjadi masalah pada pasien, kesulitan dalam mengisi form yang dibutuhkan, kehilangan barang, dll petugas selalu berusaha membantu untuk memecahkannya

\section{Hasil Dan Pembahasan}

\subsection{Hasil Penelitian}

Hasil penelitian ini berupa persepsi dan harapan pasien ditinjau dari dimensi tangible, reliability, responsiveness, assurance, emphaty.Tingkat kepuasan pasien dianalisis menggunakan metode Servqual, CSI, dan IPA.

Tabel 1. Nilai Rata-rata Persepsi dan Harapan

\begin{tabular}{cccc}
\multicolumn{3}{c}{ Dimensi Bukti Langsung } \\
\hline No & $\begin{array}{c}\text { Kode } \\
\text { Atribut }\end{array}$ & $\begin{array}{c}\text { Nilai Rata- } \\
\text { Rata Persepsi }\end{array}$ & $\begin{array}{c}\text { Nilai Rata- } \\
\text { Rata } \\
\text { Harapan }\end{array}$ \\
\hline 1 & A1 & 4,33 & 4,56 \\
2 & A2 & 4,03 & 4,63 \\
3 & A3 & 3,55 & 4,57 \\
4 & A4 & 4,18 & 4,53 \\
5 & A5 & 4,27 & 4,62
\end{tabular}

\begin{tabular}{cccc}
6 & A6 & 3,74 & 4,59 \\
7 & A7 & 4,11 & 4,59 \\
8 & A8 & 4,33 & 4,60 \\
9 & A9 & 4,28 & 4,60 \\
10 & A10 & 4,35 & 4,49 \\
11 & A11 & 4,26 & 4,47 \\
12 & A12 & 3,79 & 4,69 \\
13 & A13 & 3,94 & 4,70 \\
14 & A14 & 3,15 & 4,46 \\
15 & A15 & 3,04 & 4,60 \\
16 & A16 & 3,87 & 4,63 \\
\hline \multicolumn{2}{r}{ Rata-rata } & 3,95 & 4,58 \\
\hline
\end{tabular}

Tabel 1 menunjukkan bahwa nilai persepsi terendah adalah atribut A15 dengan nilai persepsi 3,04. Nilai persepsi tertinggi pada dimensi Bukti Langsung adalah atribut A10 dengan nilai 3,35 . Nilai harapan terendah adalah atribut A14 dengan nilai 4,46 yang dianggap kurang penting oleh responden sedangkan nilai harapan tertinggi adalah pada atribut A13 dengan nilai 4,70.

Tabel 2. Nilai Rata-rata Persepsi dan Harapan Dimensi Kehandalan (Reliability)

\begin{tabular}{cccc}
\hline No & $\begin{array}{c}\text { Kode } \\
\text { Atribut }\end{array}$ & $\begin{array}{c}\text { Nilai Rata- } \\
\text { Rata Persepsi }\end{array}$ & $\begin{array}{c}\text { Nilai Rata- } \\
\text { Rata } \\
\text { Harapan }\end{array}$ \\
\hline 1 & B17 & 4,18 & 4,76 \\
2 & B18 & 4,16 & 4,73 \\
3 & B19 & 3,80 & 4,76 \\
4 & B20 & 4,17 & 4,74 \\
5 & B21 & 4,14 & 4,72 \\
\hline
\end{tabular}

Tabel 3 menunjukkan bahwa nilai persepsi terendah pada dimensi Kehandalan (Reliability) adalah atribut B19 dengan nilai 3,80 . Nilai persepsi tertinggi adalah atribut B17 dengan nilai 4,18. Nilai harapan terendah berada pada atribut B21 dengan nilai 4,72. Harapan tertinggi terdapat pada dua atribut yaitu atribut B17 dan B19 dengan nilai yang sama yaitu 4,76 .

Tabel 3. Nilai Rata-rata Persepsi dan Harapan Dimensi Daya Tanggap (Responsiveness)

\begin{tabular}{cccc}
\hline No & $\begin{array}{c}\text { Kode } \\
\text { Atribut }\end{array}$ & $\begin{array}{c}\text { Nilai Rata- } \\
\text { Rata Persepsi }\end{array}$ & $\begin{array}{c}\text { Nilai Rata- } \\
\text { Rata } \\
\text { Harapan }\end{array}$ \\
\hline 1 & C22 & 4,18 & 4,76 \\
2 & C23 & 4,09 & 4,69 \\
3 & C24 & 3,35 & 4,79 \\
4 & C25 & 3,18 & 4,73 \\
5 & C26 & 3,94 & 4,61 \\
\hline & Rata-rata & 3,75 & 4,71 \\
\hline
\end{tabular}

Tabel 3 menunjukkan bahwa nilai persepsi terendah pada dimensi Daya Tanggap (Responsiveness) adalah atribut $\mathrm{C} 25$ dengan 
nilai 3,18. Nilai persepsi tertinggi adalah atribut C22 dengan nilai 4,18. Nilai harapan terendah adalah atribut C26 dengan nilai 4,61 sedangkan nilai harapan tertinggi adalah atribut C24 dengan nilai 4,79.

Tabel 4. Nilai Rata-rata Persepsi dan Harapan Dimensi Jaminan (Assurance)

\begin{tabular}{cccc}
\hline No & $\begin{array}{c}\text { Kode } \\
\text { Atribut }\end{array}$ & $\begin{array}{c}\text { Nilai Rata- } \\
\text { Rata } \\
\text { Persepsi }\end{array}$ & $\begin{array}{c}\text { Nilai Rata- } \\
\text { Rata } \\
\text { Harapan }\end{array}$ \\
\hline 1 & D27 & 4,11 & 4,73 \\
2 & D28 & 3,91 & 4,66 \\
3 & D29 & 4,17 & 4,78 \\
4 & D30 & 4,06 & 4,69 \\
5 & D31 & 3,76 & 4,65 \\
6 & D32 & 3,65 & 4,61 \\
7 & D33 & 4,18 & 4,68 \\
8 & D34 & 4,06 & 4,68 \\
\hline \multicolumn{4}{c}{ Rata-rata } \\
\hline
\end{tabular}

Tabel 4 menjelaskan bahwa nilai persepsi terendah adalah atribut D32 dengan nilai 3,65. Nilai persepsi tertinggi adalah atribut D33 dengan nilai 4,18. Nilai harapan terendah berada pada atribut D32 dengan nilai 4,61 sedangkan harapan tertinggi adalah atribut D29 dengan nilai 4,78.

Tabel 5. Nilai Rata-rata Persepsi dan Harapan Dimensi Empati (Emphaty)

\begin{tabular}{cccc}
\hline No & $\begin{array}{c}\text { Kode } \\
\text { Atribut }\end{array}$ & $\begin{array}{c}\text { Nilai Rata- } \\
\text { Rata } \\
\text { Persepsi }\end{array}$ & $\begin{array}{c}\text { Nilai Rata- } \\
\text { Rata } \\
\text { Harapan }\end{array}$ \\
\hline 1 & E35 & 4,27 & 4,82 \\
2 & E36 & 4,23 & 4,82 \\
3 & E37 & 4,23 & 4,75 \\
4 & E38 & 4,13 & 4,73 \\
5 & E39 & 4,29 & 4,78 \\
6 & E40 & 4,27 & 4,77 \\
7 & E41 & 4,10 & 4,75 \\
\hline & Rata-rata & 4,22 & 4,77 \\
\hline
\end{tabular}

Tabel 5 menunjukkan bahwa nilai persepsi terendah adalah atribut E41 yang memiliki nilai 4,10 sedangkan nilai persepsi tertinggi adalah atribut E39 dengan nilai 4,29. Nilai harapan terendah adalah atribut E38 dengan nilai 4,73 sedangkan nilai harapan tertinggi berada pada atribut E35 dan E36 dengan nilai 4,82 .

Berdasarkan hasil identifikasi persepsi dan harapan pada atribut di setiap dimensi mutu pelayanan yang ada, maka dapat diperoleh rata-rata persepsi dan harapan pasien pada setiap dimensi mutu pelayanan.
Hasil rata-rata persepsi dan harapan pasien pada setiap dimensi mutu pelayanan dapat dilihat pada tabel 6 .

Tabel 6. Jumlah Rata-rata Persepsi dan Harapan pada Lima Dimensi Mutu

\begin{tabular}{|c|c|c|c|}
\hline No & Variabel & $\begin{array}{c}\text { Nilai } \\
\text { Rata- } \\
\text { Rata } \\
\text { Persep } \\
\text { si }\end{array}$ & $\begin{array}{c}\text { Nilai } \\
\text { Rata- } \\
\text { Rata } \\
\text { Harap } \\
\text { an }\end{array}$ \\
\hline 1 & $\begin{array}{l}\text { Bukti Langsung } \\
\text { (Tangible) } \\
\text { Kehandalan }\end{array}$ & 3,95 & 4,58 \\
\hline 2 & (Reliability) & 4,09 & 4,74 \\
\hline 3 & $\begin{array}{l}\text { Daya Tanggap } \\
\text { (Responsiveness) }\end{array}$ & 3,75 & 4,71 \\
\hline 4 & Jaminan (Assurance) & 3,99 & 4,68 \\
\hline 5 & Empati (Emphaty) & 4,22 & 4,77 \\
\hline & Rata-rata & 4,00 & 4,70 \\
\hline
\end{tabular}

Tabel 6 menunjukkan bahwa dari persepsi responden diperoleh nilai rata-rata terendah berada pada dimensi Daya Tanggap (Responsiveness) yaitu 3,75 sedangkan persepsi tertinggi adalah dimensi Empati (Emphaty). Rendahnya nilai rata-rata pada dimensi Daya Tanggap (Responsiveness) menunjukkan bahwa kecepatan pemberi pelayanan untuk membantu merespon kebutuhan atau keinginan konsumen dengan segera masih kurang. Berdasarkan harapan responden, nilai rata-rata terendah adalah dimensi Bukti Langsung (Tangible) dengan nilai 4,58 sedangkan nilai rata-rata harapan tertinggi adalah dimensi Empati (Emphaty) yaitu 4,77 .

Tabel 7. Hasil Perhitungan Nilai SERVQUAL Pada Lima Dimensi Mutu

\begin{tabular}{clccc}
\hline No & \multicolumn{1}{c}{ Dimensi } & $\begin{array}{c}\text { Nilai } \\
\text { Rata- } \\
\text { Rata } \\
\text { Persepsi }\end{array}$ & $\begin{array}{c}\text { Nilai } \\
\text { Rata- } \\
\text { Rata } \\
\text { Harapan }\end{array}$ & $\begin{array}{c}\text { Nilai } \\
\text { SERVQUAL } \\
\text { (gap) }\end{array}$ \\
\hline 1 & $\begin{array}{l}\text { Bukti } \\
\text { Langsung } \\
\text { (Tangible) }\end{array}$ & 3,95 & 4,58 & $-0,63$ \\
2 & $\begin{array}{l}\text { Kehandalan } \\
\text { (Reliability) }\end{array}$ & 4,09 & 4,74 & $-0,65$ \\
\hline & $\begin{array}{l}\text { Daya Tanggap } \\
\text { (Responsivene } \\
\text { ss) }\end{array}$ & 3,75 & 4,71 & $-0,96$ \\
\hline 5 & $\begin{array}{l}\text { Jaminan } \\
\text { (Assurance) } \\
\text { Empati } \\
\text { (Emphaty) }\end{array}$ & 3,99 & 4,68 & $-0,69$ \\
\hline & \begin{tabular}{l} 
Rata-rata \\
\hline
\end{tabular} & 4,22 & 4,77 & $-0,55$ \\
\hline
\end{tabular}


Hasil analisis tingkat kepuasan pasien menggunakan metode SERVQUAL pada 5 dimensi mutu pelayanan yang diperoleh berdasarkan tabel 8 menunjukkan bahwa nilai SERVQUAL pada setiap dimensi mutu pelayanan di Klinik dr. M. Suherman bernilai negatif. Artinya kualitas mutu pelayanan yang diberikan oleh Klinik dr. M. Suherman belum dapat memenuhi harapan pasien. Nilai SERVQUAL terendah adalah dimensi Empati (Emphaty) dengan nilai -0,55 sedangkan nilai tertinggi adalah dimensi Daya Tanggap (Responsiveness) dengan nilai -0,96. Jadi berdasarkan pada 5 dimensi mutu pelayanan, maka pelayanan yang perlu dilakukan perbaikan utama berada pada dimensi Daya Tanggap (Responsiveness).

Tabel 8. Perhitungan Tingkat Kepuasan Pasien dengan Metode Costumer Satisfaction Index (CSI)

\begin{tabular}{|c|c|c|c|c|c|}
\hline No & $\begin{array}{c}\text { Kode } \\
\text { Atrib } \\
\text { ut }\end{array}$ & $\begin{array}{c}\text { Nilai } \\
\text { Rata- } \\
\text { Rata } \\
\text { Perseps }\end{array}$ & $\begin{array}{c}\text { Nilai } \\
\text { Rata- } \\
\text { Rata } \\
\text { Harapa }\end{array}$ & $\begin{array}{c}\text { Weight } \\
\text { Factor } \\
(\text { WF })\end{array}$ & $\begin{array}{c}\text { Weight } \\
\text { Score } \\
\text { (WS) }\end{array}$ \\
\hline & & $\mathbf{i}$ & n & & \\
\hline 1 & A1 & 4,33 & 4,56 & 2,38 & 0,103 \\
\hline 2 & A2 & 4,03 & 4,63 & 2,42 & 0,097 \\
\hline 3 & A3 & 3,55 & 4,57 & 2,39 & 0,085 \\
\hline 4 & A4 & 4,18 & 4,53 & 2,36 & 0,099 \\
\hline 5 & A5 & 4,27 & 4,62 & 2,41 & 0,103 \\
\hline 6 & A6 & 3,74 & 4,59 & 2,40 & 0,090 \\
\hline 7 & A7 & 4,11 & 4,59 & 2,40 & 0,098 \\
\hline 8 & A8 & 4,33 & 4,60 & 2,40 & 0,104 \\
\hline 9 & A9 & 4,28 & 4,60 & 2,40 & 0,103 \\
\hline 10 & A10 & 4,35 & 4,49 & 2,35 & 0,102 \\
\hline 11 & A11 & 4,26 & 4,47 & 2,34 & 0,100 \\
\hline 12 & A12 & 3,79 & 4,69 & 2,45 & 0,093 \\
\hline 13 & A13 & 3,94 & 4,70 & 2,45 & 0,097 \\
\hline 14 & A14 & 3,15 & 4,46 & 2,33 & 0,074 \\
\hline 15 & A15 & 3,04 & 4,60 & 2,40 & 0,073 \\
\hline 16 & A16 & 3,87 & 4,63 & 2,42 & 0,094 \\
\hline 17 & B17 & 4,18 & 4,76 & 2,49 & 0,104 \\
\hline 18 & B18 & 4,16 & 4,73 & 2,47 & 0,103 \\
\hline 19 & B19 & 3,80 & 4,76 & 2,49 & 0,094 \\
\hline 20 & B20 & 4,17 & 4,74 & 2,47 & 0,103 \\
\hline 21 & B21 & 4,14 & 4,72 & 2,46 & 0,102 \\
\hline 22 & $\mathrm{C} 22$ & 4,18 & 4,76 & 2,49 & 0,104 \\
\hline 23 & $\mathrm{C} 23$ & 4,09 & 4,69 & 2,45 & 0,100 \\
\hline 24 & C24 & 3,35 & 4,79 & 2,50 & 0,084 \\
\hline 25 & $\mathrm{C} 25$ & 3,18 & 4,73 & 2,47 & 0,079 \\
\hline 26 & $\mathrm{C} 26$ & 3,94 & 4,61 & 2,41 & 0,095 \\
\hline 27 & D27 & 4,11 & 4,73 & 2,47 & 0,102 \\
\hline 28 & D28 & 3,91 & 4,66 & 2,43 & 0,095 \\
\hline 29 & D29 & 4,17 & 4,78 & 2,50 & 0,104 \\
\hline 30 & D30 & 4,06 & 4,69 & 2,45 & 0,099 \\
\hline
\end{tabular}

\begin{tabular}{|c|c|c|c|c|c|}
\hline 31 & D31 & 3,76 & 4,65 & 2,43 & 0,091 \\
\hline 32 & D32 & 3,65 & 4,61 & 2,41 & 0,088 \\
\hline 33 & D33 & 4,18 & 4,68 & 2,44 & 0,102 \\
\hline 34 & D34 & 4,06 & 4,68 & 2,44 & 0,099 \\
\hline 35 & E35 & 4,27 & 4,82 & 2,52 & 0,108 \\
\hline 36 & D36 & 4,23 & 4,82 & 2,52 & 0,107 \\
\hline 37 & E37 & 4,23 & 4,75 & 2,48 & 0,105 \\
\hline 38 & E38 & 4,13 & 4,73 & 2,47 & 0,102 \\
\hline 39 & E39 & 4,29 & 4,78 & 2,50 & 0,107 \\
\hline 40 & E40 & 4,27 & 4,77 & 2,49 & 0,106 \\
\hline 41 & E41 & 4,10 & 4,75 & 2,48 & 0,102 \\
\hline \multicolumn{2}{|c|}{ Total } & $\begin{array}{c}163,8 \\
7\end{array}$ & $\begin{array}{c}191,4 \\
1\end{array}$ & 100,00 & \multirow{2}{*}{3,998} \\
\hline \multicolumn{5}{|c|}{ Weight Total (WT) } & \\
\hline \multicolumn{5}{|c|}{ mer Satisfaction Index (CSI) } & 79,958 \\
\hline
\end{tabular}

Berdasarkan Tabel 8 bobot nilai Customer Satisfaction Index (CSI) adalah $79,958 \%$. Nilai tersebut berdasarkan tabel nilai Customer Satisfaction Index berada pada $66 \%-80,99 \%$ yang berarti secara keseluruhan pasien telah merasa puas dengan pelayanan yang diberikan di Klinik dr. M. Suherman. Menurut DJSN (2012), sasaran pokok kepuasan minimal peserta BPJS tahun 2014 adalah $75 \%$ kemudian menjadi $85 \%$ pada tahun 2019. Nilai Customer Satisfaction Index (CSI) di Klinik dr. M. Suherman sebesar $79,958 \%$ artinya telah memenuhi sasaran pokok tahun 2014 tentang kepuasan minimal peserta BPJS, akan tetapi nilai tersebut perlu ditingkatkan untuk dapat memenuhi sasaran pokok kepuasan minimal peserta BPJS tahun 2019 mendatang.

Hasil analisis tingkat kepuasan pasien BPJS rawat jalan dengan metode importance permormance analysis (IPA) dapat dilihat pada gambar 1 berikut :

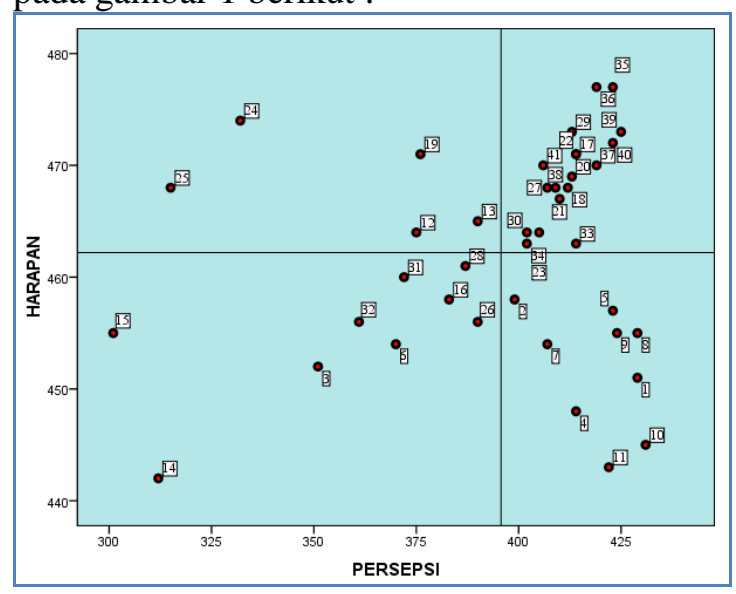

Gambar 1. Diagram Kartesius 


\subsection{Pembahasan}

Hasil pengukuran tingkat kepuasan pasien dengan menggunakan metode SERVQUAL menunjukkan bahwa pada setiap dimensi mutu pelayanan di Klinik dr. M. Suherman terdapat gap bernilai negatif yang artinya kualitas mutu pelayanan yang diberikan oleh Klinik dr. M. Suherman belum dapat memenuhi harapan pasien sehingga belum memuaskan pasien. Akan tetapi berdasarkan pengukuran tingkat kepuasan pasien dengan menggunakan metode Customer Satisfaction Index (CSI) tingkat kepuasan pasien secara menyeluruh berada pada kriteria "Puas". Hal ini disebabkan karena kriteria kepuasan pelanggan antara metode SERVQUAL dengan metode Customer Satisfaction Index (CSI) berbeda tolak ukurnya.

Gambar 1 menunjukkan bahwa letak atribut mutu pelayanan tersebar menjadi empat bagian yaitu Kuadran A (Prioritas Utama), Kuadran B (Pertahanan Prestasi), Kuadran C (Prioritas Rendah), Kuadran D (Berlebihan). Atribut yang berada pada kuadran A merupakan atribut yang perlu diprioritaskan atau diutamakan karena keberadaan atribut tersebut dinilai sangat penting oleh pasien, namun pelaksanaannya belum dapat memuaskan pasien. Atribut pada Kuadran B merupakan atribut-atribut yang perlu dipertahankan pelaksanaannya karena menurut pasien atribut-atribut ini dinilai penting serta pelaksanaannya sudah sesuai dengan harapan pasien. Atribut pada Kuadran $\mathrm{C}$ merupakan atribut yang dinilai kurang penting bagi pasien, sedangkan kualitas pelaksanaanya juga belum memadai, akan tetapi prioritasnya masih dibawah prioritas atribut pada kuadran A. Sedangkan atribut yang berada pada Kuadran D atribut-atribut yang dinilai berlebihan dalam pelaksanaannya.

Dari empat kuadran tersebut dapat dilihat bahwa atribut yang perlu diprioritaskan untuk dilakukan perbaikan kualitas pelayanan adalah atribut yang berada pada kuadran A. Oleh karena itu pembahasan pada metode Importance Performance Analysis (IPA) ini hanya akan difokuskan pada atribut yang berada pada Kuadran A. Dapat dilihat pada gambar 1 bahwa pada Kuadran A terdapat lima atribut sebagai berikut : a. Kamar mandi dalam kondisi bersih, tidak terdapat kotoran dalam bak air maupun kotoran yang menyumbat saluran air (Atribut 12)

Kenyataan berdasarkan pada persepsi pasien adalah kamar mandi tidak dalam kondisi bersih karena adanya kotoran baik didalam bak mandi maupun kotoran yang menyumbat kamar mandi sehingga ketika ingin ke kamar mandi pasien merasa tidak nyaman. Menurut Kemenkes RI (2014) menyatakan bahwa bangunan klinik harus memenuhi persyaratan lingkungan sehat, memperhatikan fungsi, keamanan, kenyamanan dan kemudahan dalam memberikan pelayanan. Telah diketahui bahwa suatu lingkungan yang kotor merupakan sarana penyebaran penyakit. Oleh karena itu, perbaikan pada atribut pelayanan ini dapat dilakukan dengan meningkatkan kinerja petugas kebersihan terutama yang bertugas dalam membersihkan kamar mandi. Petugas kebersihan hendaknya membersihkan kamar mandi teratur.

b. Terdapat mushola dalam kondisi bersih, tidak terdapat sampah atau kotoran yang menyebabkan najis (Atribut 13)

Penyediaan fasilitas ibadah seperti mushola merupakan hal yang peting untuk dilakukan mengingat bahwa ibadah merupakan kewajiban setiap manusia yang tidak dapat ditinggalkan. Kebersihan mushola merupakan hal yang penting bagi setiap orang karena dalam beribadah tidak boleh terdapat kotoran yang menyebabkan najis. Akan tetapi, menurut pasien mushola masih terlihat adanya kotoran yang dapat menyebabkan najis sehingga penggunaan mushola untuk beribadah bagi pasien belum dapat memenuhi harapan pasien. Menurut Muninjaya (2004) kepuasan pengguna jasa dipengaruhi oleh penampilan fisik petugas, kondisi kebersihan dan kenyamanan ruangan. Maka untuk menanggapi keluhan pasien pada atribut ini dapat dilakukan dengan memperbaiki kinerja petugas kebersihan yang bertanggung jawab terhadap kebersihan mushola. 
c. Dokter telah hadir diruang pemeriksaan dan siap melayani pasien ketika jam buka rawat jalan dimulai (pagi : 08.00-13.00, sore 16.00-21.00) (Atribut 19)

Kehadiran dokter tepat waktu sangat mempengaruhi kepuasan pasien. Hal ini sejalan dengan hasil penelitian yang dilakukan oleh David, et al (2014) yang menyatakan bahwa terdapat hubungan yang bermakna antara tingkat kepuasan pasien dengan ketepatan waktu kedatangan dokter untuk menangani pasien di unit rawat jalan. Ketepatan waktu kedatangan dokter dalam melayanai pasien akan semakin meningkatkan kepuasan pasien, sebaliknya apabila dokter datang tidak tepat waktu untuk melayani pasien di unit rawat jalan, maka hal ini akan semakin menurunkan kepuasan pasien.

d. Waktu tunggu pasien untuk mendapatkan pelayanan rawat jalan kurang dari 60 menit (Atribut 24)

Kondisi yang terjadi menurut pasien adalah waktu tunggu untuk mendapatkan pemeriksaan dokter dipoli tidak sesuai dengan standar yaitu kurang dari 60 menit, ketidaksesuaian ini sering dikeluhkan oleh pasien terutama pada pasien di poli gigi. Menurut Candra dalam David, et al (2014), salah satu indikator kepuasan pasien adalah waktu tunggu, dimana waktu tunggu yang lama terhadap pelayanan medis maupun non medis pada unit rawat jalan dan rawat inap akan mengurangi kepuasan pasien. Oleh karena itu, untuk perbaikan pelayanan maka diharapkan agar dokter dapat meningkatkan kecepatan dalam memberikan pelayanan kepada pasien, tentunya tanpa mengurangi ketepatan dalam pelayanannya.

e. Waktu tunggu pasien untuk mendapatkan obat dari apotek kurang dari 30 menit untuk obat jadi (Atribut 25)

Kondisi yang terjadi adalah waktu pasien menunggu untuk mendapatkan obat dari apotek melebihi standar waktu yaitu kurang dari 30 menit, kenyataan yang terjadi adalah waktu pasien menunggu untuk mendapatkan obat dari apotek adalah 45-75 menit dengan rata-rata waktu tunggu adalah 53,6 menit. Hal ini dapat disebabkan karena kurangnya loket obat ataupun jumlah petugas bagian apotek yang memberikan pelayanan obat kepada pasien. Oleh karena itu, pihak manajemen klinik dapat mempertimbangkan penambahan jumlah loket obat ataupun petugas apotek. Menurut Candra dalam David, et al (2014), salah satu indikator kepuasan pasien adalah waktu tunggu, dimana waktu tunggu yang lama terhadap pelayanan medis maupun non medis pada unit rawat jalan dan rawat inap akan mengurangi kepuasan pasien. Waktu tunggu pasien yang sesuai dengan standar pelayanan minimal akan meningkatkan kualitas pelayanan serta kepuasan pasien.

Metode Importance Performance Analysis (IPA) merupakan suatu metode yang dapat digunakan untuk mengetahui pelayanan kesehatan yang harus ditingkatkan dengan menggunakan diagram kartesius dengan membagi atribut pelayanan kedalam empat kuadran yang selanjutnya akan dihasilkan suatu perhitungan mengenai tingkat kesesuaian antara persepsi dan harapan kinerja layanan.

Berikut adalah hasil perbandingan setiap skor serta tingkat kesesuaian pada masingmasing atribut pada Kuadran A (Prioritas Utama) yang diperoleh:

Tabel 9 Tingkat Kesesuaian

\begin{tabular}{|c|c|c|c|c|c|}
\hline No & $\begin{array}{c}\text { Kode } \\
\text { Atribut }\end{array}$ & $\begin{array}{c}\text { Skor } \\
\text { Perseps } \\
\text { i }\end{array}$ & $\begin{array}{c}\text { Skor } \\
\text { Harapa } \\
\text { n }\end{array}$ & $\begin{array}{c}\text { Tingkat } \\
\text { Kesesuaian }\end{array}$ & $\begin{array}{l}\text { Priorita } \\
\mathrm{S}\end{array}$ \\
\hline 1 & A12 & 375 & 464 & $80,82 \%$ & 4 \\
\hline 2 & A13 & 390 & 465 & $83,87 \%$ & 5 \\
\hline 3 & B19 & 376 & 471 & $79,83 \%$ & 3 \\
\hline 4 & $\mathrm{C} 24$ & 332 & 474 & $70,04 \%$ & 2 \\
\hline 5 & $\mathrm{C} 25$ & 315 & 468 & $67,31 \%$ & 1 \\
\hline
\end{tabular}

Hasil dari tabel 9 menunjukkan bahwa tingkat kesesuaian tertinggi dari 5 atribut tersebut berada pada atribut terdapat mushola dalam kondisi bersih, tidak terdapat sampah atau kotoran yang menyebabkan najis (A13) yaitu 83,87\% dengan angka prioritas ke-5. Artinya untuk mencapai kepuasan pelanggan, maka perbaikan kualitas pelayanan pada atribut A16 menjadi prioritas yang ke-5.

Tingkat kesesuaian terendah terdapat pada atribut waktu tunggu pasien untuk mendapatkan obat dari apotek kurang dari 30 menit (C25) yaitu 67,31\% sehingga memiliki prioritas tertinggi yaitu 1 (pertama). Peningkatan terhadap atribut ini harus diutamakan untuk dapat memberikan kepuasan kepada pasien karena atribut dengan 
prioritas tinggi sangat diharapkan oleh pasien akan tetapi pada kenyataannya menurut pasien belum sesuai dengan harapan sehingga belum dapat memberikan kepuasan.

\section{Kesimpulan}

Berdasarkan hasil penelitian terhadap 99 pasien BPJS yang mendapatkan pelayanan rawat jalan di Klinik dr. M. Suherman dan perhitungan yang telah dilakukan, dapat disimpulkan bahwa :

a. Dimensi Bukti Langsung (Tangible) nilai persepsi terendah adalah atribut terdapat pusat pengaduan atau customer service yang dapat dihubungi langsung dibagian pengaduan atau via telepon.

b. Dimensi Kehandalan (Reliability) nilai persepsi terendah adalah atribut dokter telah hadir diruang pemeriksaan dan siap melayani pasien ketika jam buka rawat jalan dimulai (pagi : 08.00-13.00, sore 16.00-21.00).

c. Dimensi Daya Tanggap (Responsiveness) nilai persepsi terendah adalah atribut waktu tunggu pasien untuk mendapatkan obat jadi dari apotek kurang dari 30 menit.

d. Dimensi Jaminan (Assurance) nilai persepsi terendah adalah atribut petugas apotek melayani dengan senyum, ramah dan sopan.

e. Dimensi Empati (Emphaty) nilai persepsi terendah adalah atribut ketika terjadi masalah pada pasien, kesulitan dalam mengisi form yang dibutuhkan, kehilangan barang, dll petugas selalu berusaha membantu untuk memecahkannya.

f. Tingkat kepuasan pasien BPJS yang mendapatkan pelayanan rawat jalan di Klinik dr. M. Suherman dengan menggunakan metode SERVQUAL masing-masing dimensi mutu menunjukkan adanya gap bernilai negatif.

g. Tingkat kepuasan pasien BPJS yang mendapatkan pelayanan rawat jalan di Klinik dr. M. Suherman dengan metode Customer Satisfaction Index (CSI) adalah $79,958 \%$ menunjukkan bahwa secara keseluruhan pasien "Puas".

h. Hasil analisis dengan metode Importance Performance Analysis (IPA) menyatakan bahwa terdapat 5 atribut pelayanan pada Kuadran A (Prioritas Utama) dengan prioritas tertinggi adalah waktu tunggu pasien untuk mendapatkan obat dari apotek kurang dari 30 menit.

Berdasarkan hasil dari kesimpulan dalam penelitian ini, berikut adalah beberapa saran yang dikemukakan peneliti agar dapat dijadikan bahan pertimbangan dalam proses perbaikan pelayanan kesehatan pasien BPJS yang mendapatkan pelayanan rawat jalan di Klinik dr. M. Suherman, diantaranya :

a. Petugas apotek hendaknya lebih memperhatikan standar waktu pelayanan obat kepada pasien, sehingga dalam memberikan pelayanan tidak melebihi standar waktu yang ditentukan.

b. Dokter diharapkan untuk lebih memperhatikan ketepatan waktu dalam memberikan pelayanan rawat jalan sesuai dengan jam buka pelayanan.

c. Diperlukan adanya standar operasional prosedur terkait ketepatan waktu kehadiran petugas

d. Sebaiknya pihak manajemen klinik melakukan evaluasi setiap bulan terkait ketepatan waktu kehadiran petugas dan ketepatan waktu pelayanan pasien sesuai standar yang berlaku.

e. Petugas kebersihan hendaknya membersihkan pada kamar mandi dan mushola secara teratur.

f. Penelitian selanjutnya disarankan dapat meneliti tentang faktor-faktor penyebab ketidaksesuaian waktu tunggu pasien di loket obat yang lebih dari 30 menit.

\section{Daftar Pustaka}

David, Hariyanti, T., Widayanti. 2014. "Hubungan Keterlambatan Kedatangan Dokter Terhadap Kepuasan Pasien di Instalasi Rawat Jalan”. Jurnal Kedokteran Brawijaya. Hal 3-4

Dewan Jaminan Sosial Nasional. 2012. Peta Jalan Menuju Jaminan Sosial Nasional 2012-2019. Jakarta

Pohan, I. S. 2006. Jaminan Mutu Layanan Kesehatan. Jakarta: ECG

Puspitasari, R. 2013. Kepuasan Pasien Jamsoskes Terhadap Pelayanan Kesehatan di Instalasi Rawat Inap 
ISSN : 2354-5852

e-ISSN : 2579-5783

Rumah Sakit Jember Klinik dengan Metode Servqual dan Importance Performance Analysis (IPA). Skripsi. Politeknik Negeri Jember

Rahayu, I. 2016. Sistem Pendukung Keputusan untuk Menganalisa Tingkat Kepuasan Pelanggan dengan Metode Servqual dan Importance Performance Analysis (IPA). Skripsi. Universitas Islam Negeri Sunan Kalijaga

Menteri Kesehatan RI. 2014. Peraturan Menteri Kesehatan Republik Indonesia Nomor 9 Tahun 2014 tentang Klinik. Jakarta. 